\title{
Bioethanol production from rice straw by popping pretreatment
}

\author{
Seung Gon Wi ${ }^{1}$, In Seong $\mathrm{Choi}^{2}$, Kyoung Hyoun $\mathrm{Kim}^{3}$, Ho Myeong Kim ${ }^{3}$ and Hyeun-Jong Bae ${ }^{1,2,3^{*}}$
}

\begin{abstract}
Background: Rice straw has considerable potential as a raw material for bioethanol production. Popping pretreatment of rice straw prior to downstream enzymatic hydrolysis and fermentation was found to increase cellulose to glucose conversion efficiency. The aim of this study was to investigate the influence of popping pretreatment and determine the optimal enzyme loading using a surface response design.

Results: The optimal doses of cellulase and xylanase enzymes were $23 \mathrm{FPU}$ and $62 \mathrm{lU} / \mathrm{g}$ biomass, respectively. Using the optimized enzyme condition and popping pretreatment of rice straw (15\% substrate loading, w/v), a sugar recovery of $0.567 \mathrm{~g} / \mathrm{g}$ biomass (glucose; $0.394 \mathrm{~g} / \mathrm{g}$ ) was obtained in $48 \mathrm{~h}$, which was significantly higher than that from untreated rice straw (total sugar recovery; $0.270 \mathrm{~g} / \mathrm{g}$ biomass). Fermentation of the hydrolyzates by Saccharomyces cerevisiae resulted in $0.172 \mathrm{~g}$ ethanol/g biomass after $24 \mathrm{~h}$, equivalent to $80.9 \%$ of the maximum theoretical yield (based on the amount of glucose in raw material). Changes in the chemical composition and surface area of rice straw were also investigated before and after popping pretreatment. The results showed little or no difference in chemical composition between the pretreated rice straw and the control. However, the surface area of pretreated rice straw increased twofold compared to the control.
\end{abstract}

Conclusion: Popping pretreatment of rice straw can effectively improve downstream saccharification and fermentation, important for bioethanol production.

Keywords: Popping pretreatment, Rice straw, Bioethanol, Enzymatic hydrolysis, Fermentation

\section{Background}

Bioethanol is currently produced primarily from sugar and starch sourced from crops (first-generation biomass) such as sugar cane, wheat and corn, which have a high concentration of sugar [1,2]. However, because these crops are also important food sources bioethanol produced from them can have a significant impact on food prices and food security [2]. In contrast, lignocellulosic biomass, residues from wood or dedicated energy crops (second generation) is an attractive alternative because there is no competition with food and animal feed production, and these materials are also cheaper than first-generation biomass [3,4]. Additionally, the use of lignocellulosic materials as liquid fuels can aid in reducing greenhouse gas emissions [5-7].

\footnotetext{
* Correspondence: baehj@chonnam.ac.kr

${ }^{1}$ Bio-energy Research Center, Chonnam National University, Gwangju 500-757, Republic of Korea

${ }^{2}$ Department of Forest Products and Technology, Chonnam National University, Gwangju 500-757, Republic of Korea

Full list of author information is available at the end of the article
}

Lignocellulosic biomass is the largest source of hexose and pentose sugars, which can be used for the production of bioethanol [8]. Unlike first-generation biomass, in second-generation lignocellulosic substrates cellulose in the cell wall is encased within hemicellulose and lignin matrix, and thus accessibility of cellulose is a major problem in bioethanol production from such sources. Thus, the cost of bio-fuel production is high due to intensive labor and increased processing steps. These economic and technical obstacles must be overcome for efficient and cost effective biological conversion of lignocellulosic biomass into biofuels.

Rice straw is an abundant lignocellulosic waste material in many parts of the world. Rice straw production amounts to approximately 731 million tons per year globally, with distribution in Africa (20.9 million tons), Asia (667.6 million tons), and Europe (3.9 million) [9]. Rice straw is one of the largest biomass feedstocks, and potentially 730 billion liters of bioethanol can be produced per year from the above quantity of available biomass. It is the largest amount

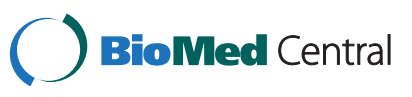


from a single biomass feedstock. Presently, high value utilization potential of this biomass remains largely uptapped. Its accumulation in the soil deteriorates the ecosystem via disposal as a waste, and burning in the field air pollution thus which can affect human health [9].

Rice straw consists of cellulose, hemicellulose and lignin. Because cellulose is embedded in a lignin matrix, pretreatment of the lignocellulosic material is needed to enhance the accessibility of this substrate for the conversion of cellulose to glucose. There are a number of biological, physical and chemical technologies available for the pretreatment of lignocellulosic biomass, including use of enzymes, ball milling, steam explosion, acid, alkali, lime and wet oxidation. The slow action of biologically-based pretreatment processes [10], and high cost of ammonia fiber explosion and hot water pretreatment make the processes economically infeasible $[11,12]$. Therefore, the development of an efficient, costeffective and environmentally friendly pretreatment method is important [13].

Recently, some new pretreatment technologies have attracted much attention, one of which is popping pretreatment [14-16]. This method is similar to water impregnated steam explosion method, which combines mechanical forces of the sudden explosion with chemical effects from hydrolysis in high temperature water and acetic acid formed from acetyl groups in the biomass. Unlike this method, however, the machine used to undertake popping pretreatment is a very simple system consisting of direct burner and rotary reactor without steam generator. This method offers key advantages over other processes, including significantly lower environmental impact and greater saccharification efficiency over similar methods used conventionally [14], with greater efficiency likely resulting from modification of the substrate that greatly enhances accessibility of desired cell wall components to enzymes. We examined the use of rice straw for ethanol production using the popping pretreatment method developed in our laboratory. Furthermore, the effect of pretreatment on rice straw was tested using downstream processing technologies. Although cellulose enzyme was the main focus of enzymatic saccharification in our study, xylanase was also included with a view to achieving fermentation also xylose with xylose specific yeast in future studies. Additionally, xylanase seemed to have worked synergistically with cellulase.

\section{Results and discussion}

\section{Chemical composition}

The neutral sugar content of rice straw was determined using GC. The composition of straw comprised pentose (24.0\%) and hexose (43.7\%) sugar, lignin (15.3\%) and ash (11.0\%) (Table 1). Glucose and xylose were the predominant component sugars in control rice straw, comprising about 41 and $20 \%$ of total dry mass, respectively. A small amount of arabinose (3.3\%) was present, indicating that the main side chain of the xylan backbone is arabinoxylan. After popping pretreatment, arabinose and xylose contents decreased (Table 1). There was little or no decrease in glucose and lignin contents. The formation of furfural and HMF, byproducts of carbohydrate degradation, was not observed.

\section{Characterization of surface area}

Generally, the Brunauer, Emmett and Teller (BET) equation is used to measure and compare the specific surface areas of a variety of porous materials. The BET surface areas of control and pretreated rice straw were measured by nitrogen adsorption isotherms using a BET surfacearea analyzer. The BET surface areas of control and pretreated rice straw were $1.5433 \mathrm{~m}^{2} / \mathrm{g}$ and $2.9346 \mathrm{~m}^{2} / \mathrm{g}$, respectively (Figure 1). This suggests that the decrease in xylose and arabinose contents (Table 1) that occurred after popping pretreatment resulted in nearly twofold increase in the surface area $[17,18]$.

The morphology of rice straw was studied using FESEM (Additional file 1: Figure S1). The surface morphology of pretreated rice straw (Additional file 1: Figure S1d-f) differed markedly from that of control rice straw (Additional file 1: Figure S1a-c). Pretreated rice straw had a rough and porous surface with identifiable micropores (Additional file 1: Figure S1f). The rougher surface and a higher surface area resulting from the removal of hemicelluloses by the popping method enhanced enzymatic hydrolysis, as has generally been considered [17]. These results are consistent with those for rapeseed straw pretreated by the popping method [14].

\section{Optimization of enzyme loading and saccharification}

Enzymatic hydrolysis is a key step in the bioconversion of cellulose to ethanol, and the focus of our research was to improve the yield and rate of enzymatic hydrolysis. Xylanse is known to have a synergetic effect on cellulose hydrolysis by degrading heterogenous xylan polymer that surrounds cellulose microfibrils [14]. Indeed, the supplementation of non-cellulolytic enzymes such as xylanase, pectinase, feruloyl esterase has been known to enhance hydrolysis of lignocellulosic biomass [19]. This is the reason why we used the complex of cellulase and xylanase as a cocktail in this study. The optimization of the enzyme ratio affecting saccharification was carried out following the factorial design of experiments and response surface methodology with factors limited to enzyme loading. We chose the $40 \mathrm{FPU}$ celluase/g biomass as the upper limit, using central point as the median in the range, as there was no further increased in the hydrolysis yield and sugar content above 
Table 1 Sugar and lignin compositions of rice straw, expressed as percentages of dry matter

\begin{tabular}{|c|c|c|c|c|c|c|c|c|c|c|}
\hline & \multicolumn{2}{|l|}{ Pentose } & \multicolumn{4}{|l|}{ Hexose } & \multirow[t]{2}{*}{ Total } & \multicolumn{2}{|l|}{ Lignin } & \multirow[t]{2}{*}{ Ash } \\
\hline & Arabinose & Xylose & Rhamnose & Mannose & Galactose & Glucose & & Acid insoluble & Acid soluble & \\
\hline Control & $3.3 \pm 0.2$ & $20.7 \pm 0.2$ & $0.3 \pm 0.0$ & $0.5 \pm 0.2$ & $1.2 \pm 0.2$ & $41.7 \pm 2.2$ & $67.8 \pm 3.2$ & $13.0 \pm 0.2$ & $2.3 \pm 0.1$ & $11.0 \pm 0.5$ \\
\hline Popping & $1.8 \pm 0.0^{* *}$ & $19.3 \pm 0.2^{* *}$ & $0.4 \pm 0.0$ & $0.5 \pm 0.0$ & $0.9 \pm 0.2$ & $41.5 \pm 3.6$ & $64.5 \pm 4.5$ & $12.2 \pm 0.7$ & $2.1 \pm 0.1$ & $11.4 \pm 0.1$ \\
\hline
\end{tabular}

this level of enzyme loading. However, the reason remained unclear. It maybe relates to enzyme absorption on substrates, but this is a speculation. Table 2 shows the experimental matrix for the statistical $2^{2}$ factorial design. The effects and interaction of cellulase and xylanase were estimated using a test of statistical significance (Additional file 2: Table S1). $P$ values $>$ F less than 0.0500 indicate that model terms are significant. Cellulase loading was the most significant variable with a positive effect on enzymatic saccharification. Also, xylanase supplement appeared to enhance the increases in enzymatic hydrolysis yield. Experimental data were fitted to a quadratic model, and the following expression was obtained.

Response $=5.78+0.53 \cdot$ cellulase $+0.047 \cdot x y l a n a s e-0.088 \cdot$ cellulase $x y l a n a s e-0.39 \cdot$ cellulase $^{2}-0.14 \cdot x$ lanase $^{2}$.

The relationship between the response and enzymes is visualized by the response surface, while the contour plot gives information about the extent of influence of the parameters (Figure 2). The optimum cellulase to xylase ratio was determined by solving the regression equation; this gave values of 23 FPU cellulase and 62 IU xylanase/g DM. Model verification was performed in three additional trials using the optimized enzyme mixture and was compared to the value predicted by the model. The predicted reducing sugar value was $5.8 \mathrm{mg} / \mathrm{mL}$ (Conversion ratio, 86.9\%) on the 1\% DM loading; the experimental results $(85.0 \pm 1.6 \mathrm{mg} / \mathrm{mL} ; 85.0 \%)$ on the $15 \%$

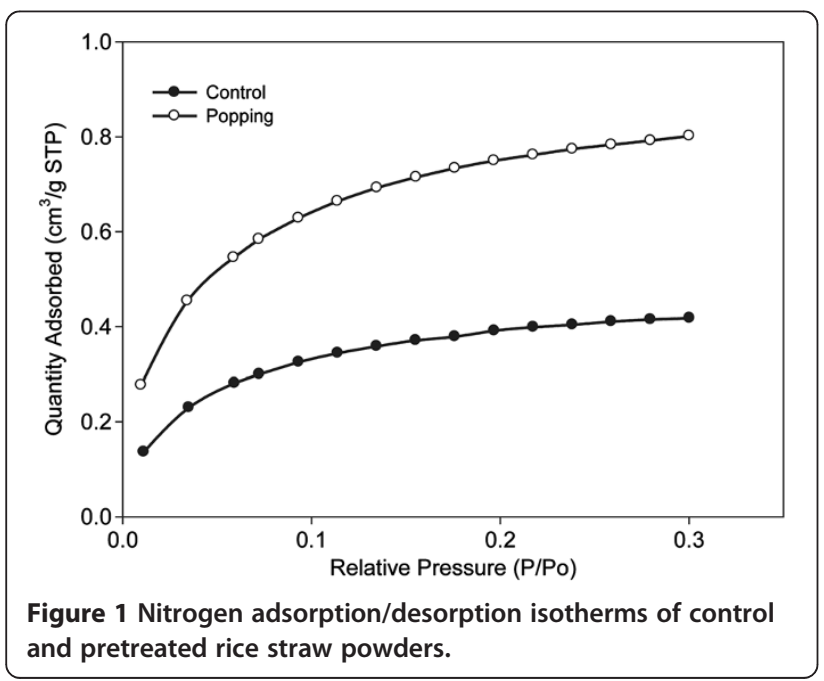

DM loading were similar, indicating that the enzyme mixture validation results were satisfactory (Figure 3). Because enzymes are expensive it was considered that using 1\% DM to determine the optimum ratio of enzymes would be a considerable saving on the cost.

\section{Separate hydrolysis and fermentation (SHF)}

To meet economical feasibility in ethanol processes from lignocellulose biomass, high tilter of ethanol must be achieved. For $2^{\text {nd }}$ generation bioethanol fermentation, a high solids loading of the pretreated feedstock close to $30 \%(\mathrm{w} / \mathrm{w})$ is required to reach the ethanol concentration up to $5 \%(\mathrm{w} / \mathrm{w})$. However, solid loading above $15 \%$ level may not result in greater cellulose conversion in enzymatic hydrolysis or in SSF process, owing to high viscosity and mass transfer [20]. Thus, enzymatic hydrolysis and fermentation experiments were carried out at $15 \%(\mathrm{w} / \mathrm{v})$ solid loading. Enzymatic hydrolysis of popping-pretreated rice straw resulted in a $3.2 \mathrm{~g} / \mathrm{L}$ h reducing sugar productivity during the first $24 \mathrm{~h}$, and in a reducing sugar concentration of $85.0 \mathrm{~g} / \mathrm{L}$ (glucose; $58.5 \mathrm{~g} / \mathrm{L}$ ) after $48 \mathrm{~h}$; corresponding to an $87.2 \%$ overall glucose recovery (based on the glucose content in raw material) (Figure 3). In case of rice straw that had not been pretreated, productivity and the final concentration of reducing sugar were $1.3 \mathrm{~g} / \mathrm{L} \mathrm{h}$ and $40.4 \mathrm{~g} / \mathrm{L}$ (glucose: $22.5 \mathrm{~g} / \mathrm{L})$, respectively. In our study, the ethanol concentration in popping pretreated rice straw reached $25.8 \mathrm{~g} / \mathrm{L}$,

Table 2 Experimental matrix for the factorial design and center points

\begin{tabular}{cccc}
\hline Run & \multicolumn{2}{c}{ Coded values } & $\begin{array}{c}\text { Reducing sugar }(\mathbf{m g} / \mathbf{m L}) \\
\text { Experimental }\end{array}$ \\
\cline { 2 - 3 } & $\boldsymbol{x}_{\mathbf{1}}$ & $\boldsymbol{x}_{\mathbf{2}}$ & 5.132 \\
$\mathbf{1}$ & -1 & 1 & 5.716 \\
$\mathbf{2}$ & 1 & -1 & 4.897 \\
$\mathbf{3}$ & -1 & -1 & 2.902 \\
$\mathbf{4}$ & -2 & 0 & 5.309 \\
$\mathbf{5}$ & 0 & 2 & 5.088 \\
$\mathbf{6}$ & 0 & -2 & 5.807 \\
$\mathbf{7}$ & 0 & 0 & 5.667 \\
$\mathbf{8}$ & 0 & 0 & 5.444 \\
$\mathbf{9}$ & 2 & 0 & 5.601 \\
$\mathbf{1 0}$ & 1 & 1 & 5.717 \\
$\mathbf{1 1}$ & 0 & 0 & \\
\hline
\end{tabular}



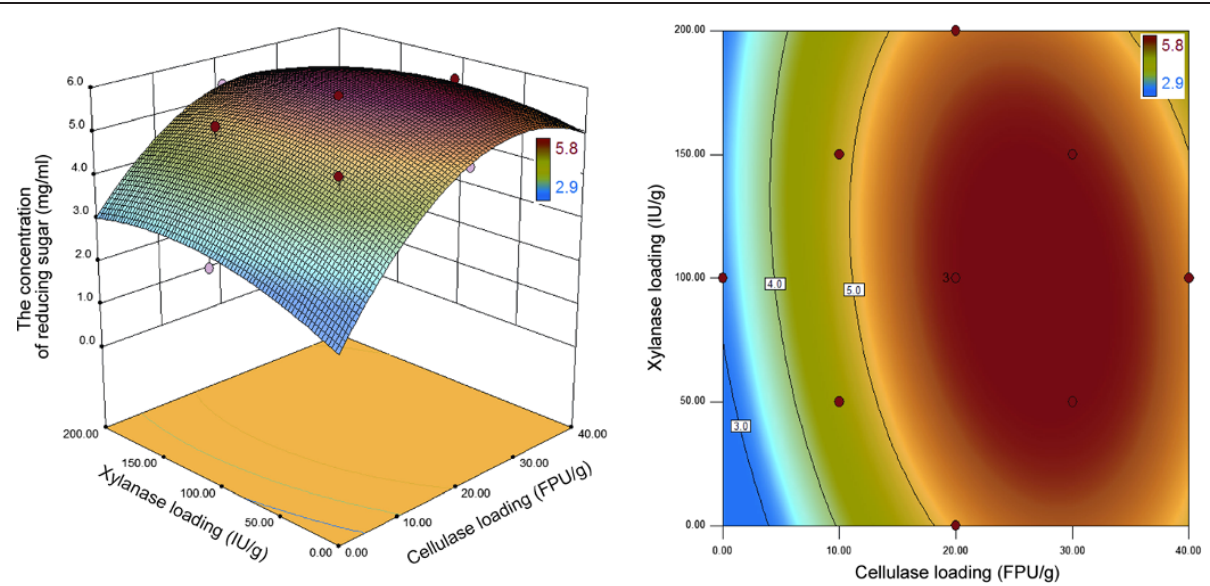

Figure 2 Response surface plot of central composite design for the optimization of the enzymatic hydrolysis of popping-pretreated rice straw.

which was based on enzymatic hydrolysis assuming $85.6 \%$ fermentation yield within a $24 \mathrm{~h}$ period $(0.44 \mathrm{~g}$ ethanol/g glucose) (Figure 4). The remaining xylose is a pentose sugar that cannot be digested by S. cerevisiase [21]. The ethanol yield in this study was $\sim 0.44 \mathrm{~g} / \mathrm{g}$, which is in accordance with those reported previously [22-25]. However, the ethanol concentration achieved in this study was not higher than $40 \mathrm{~g} / \mathrm{L}$, which is required for feasible distillation. Therefore, in order to achieve higher concentration of ethanol attractive for industrial application, higher rice straw loading is necessary.

\section{Mass balance}

Using composition analyses after each step, we developed an overall mass balance for our operation, including the

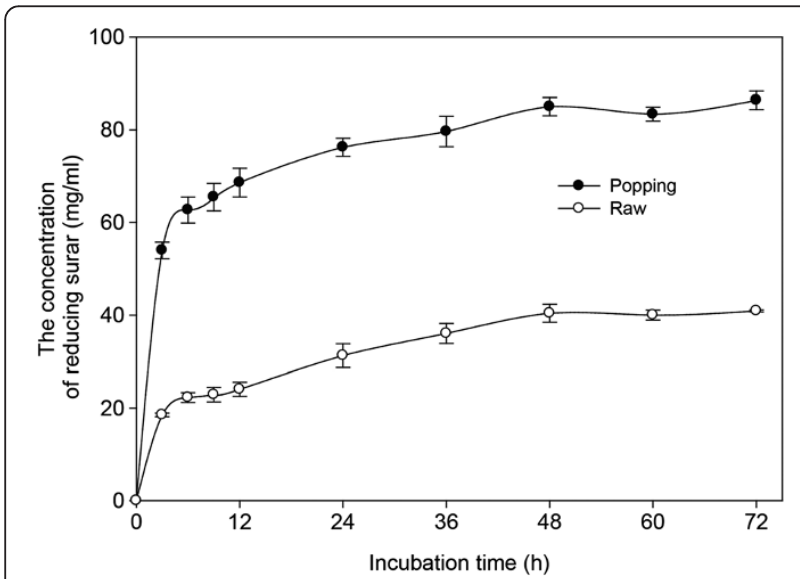

Figure 3 Changes in reducing sugar produced from control and popping-pretreated (at $220^{\circ} \mathrm{C}$ and $1.96 \mathrm{MPa}$.) rice straw at $15 \%$ DM over time as determined by the DNS method in experiments using an optimized cellulase to xylanase ratio for $72 \mathrm{~h}$ of enzymatic hydrolysis. popping pretreatment, enzymatic hydrolysis, and fermentation steps (Figure 5). Rice straw, after popping pretreatment, can be successfully converted to ethanol by the SHF process. After popping pretreatment, $2 \mathrm{~g}$ glucose and $14 \mathrm{~g}$ xylose/ $1 \mathrm{~kg}$ raw material were decreased. Total sugar after popping pretreatment recovered was $650 \mathrm{~g}$, which is not too far off from the theoretical maximum of $678 \mathrm{~g}$ for $1 \mathrm{~kg}$ raw material. From the enzymatic hydrolysis step, $394 \mathrm{~g}$ of glucose and $173 \mathrm{~g}$ of xylose were obtained per $1 \mathrm{~kg}$ of pretreated rice straw, when $23 \mathrm{kFPU}$ of cellulase and $62 \mathrm{kIU}$ of xylanase per $\mathrm{kg}$ rice straw were used. Fermentation of the hydrolyzates by Saccharomyces cerevisiae resulted in $0.172 \mathrm{~g}$ ethanol/g biomass after $24 \mathrm{~h}$, equivalent to $80.9 \%$ of the maximum theoretical yield (based on the amount of glucose in raw material). The xylose content was fairly high

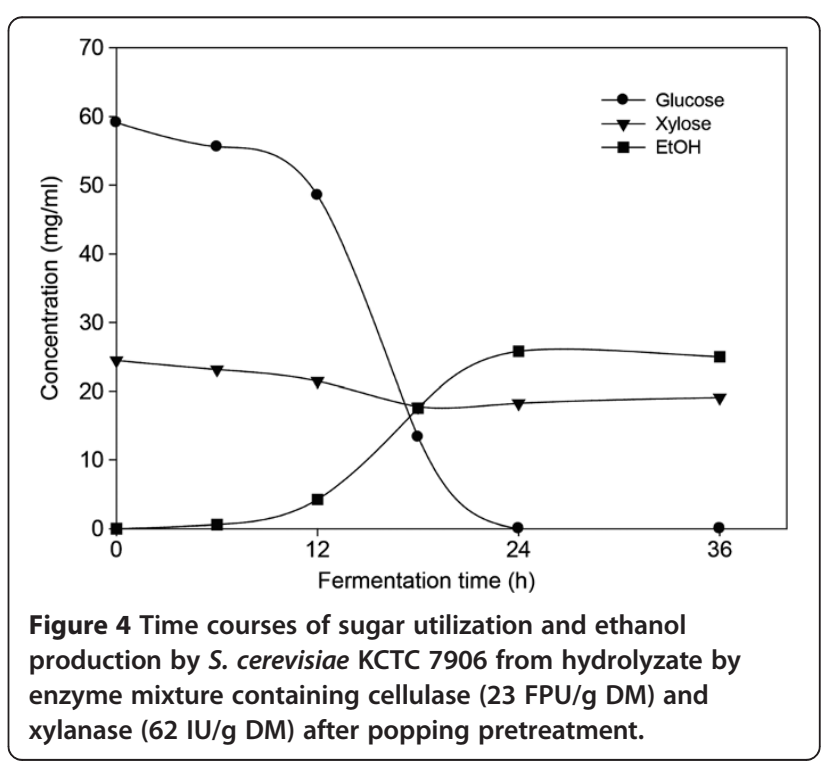




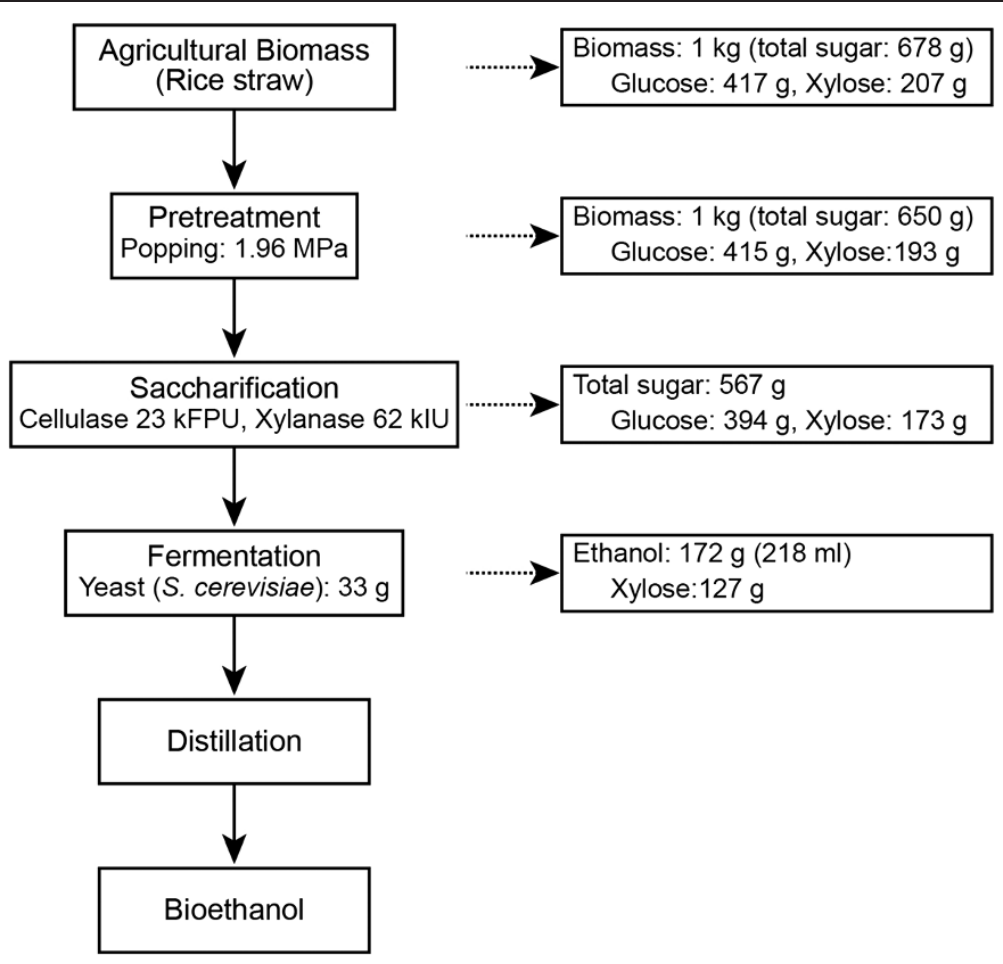

Figure 5 Overall mass balance for the popping pretreatment, enzymatic saccharification and fermentation.

after the popping pretreatment indicated that at the end of the SHF lower ethanol yield mainly resulted from inefficient utilization of xylose by yeast. Future work may also include fermentation of xylose with specific yeast such as Pichia stipitis.

\section{Conclusion}

Popping pretreatment of rice straw prior to downstream enzymatic hydrolysis and fermentation increased the efficiency of conversion of cellulose to glucose. The optimal cellulase and xylanase doses for popping pretreated rice straw at $220^{\circ} \mathrm{C}$ and $1.96 \mathrm{MPa}$ were $23 \mathrm{FPU}$ and $62 \mathrm{IU} / \mathrm{g}$, respectively. Using the optimized enzyme condition and popping pretreatment (15\% substrate loading, w/v), sugar recovery of $0.567 \mathrm{~g} / \mathrm{g}$ biomass (glucose; $0.394 \mathrm{~g} / \mathrm{g}$ biomass) was achieved in $48 \mathrm{~h}$, which was significantly higher than that obtained from rice straw that had not been pretreated (total sugar recovery; $0.270 \mathrm{~g} / \mathrm{g}$ biomass). Fermentation of the hydrolyzates with $S$. cerevisiae yielded $0.172 \mathrm{~g}$ ethanol $/ \mathrm{g}$ untreated biomass after $24 \mathrm{~h}$, equivalent to $80.9 \%$ of the theoretical yield based on the glucose content of raw material. There was little or no difference between the chemical composition of control and pretreated rice straw. However, the surface area of pretreated rice straw increased twofold over the control. The results obtained suggest that popping pretreatments brought about favorable changes to the substrate, such as increased surface area and larger pore volume, resulting from hemicellulose degradation, which greatly enhanced enzymatic accessibility of the substrate, leading to more efficient hydrolysis of cellulose. Popping pretreatment of rice straw can effectively improve downstream saccharification and fermentation, important for bioethanol production.

\section{Materials and Methods}

\section{Raw material and popping pretreatment}

Rice straw harvested in 2011 was chopped into small pieces of $\sim 2 \mathrm{~cm}$ in length with a cutter, ground with a wet-disc mill (particle size: $0.7 \pm 0.2 \mathrm{~cm}$ ) and then kept refrigerated until use. Popping pretreatment was performed in a laboratory-scale cast iron cylindrical reactor with a total volume of $3 \mathrm{~L}$, as described in a previous work [14]. The reactor was filled with $400 \mathrm{~g}$ of disc-milled feedstock (moisture content $75 \%$ ) per batch. That was directly heated with a gas burner at a rate of between 15 and $20^{\circ} \mathrm{C} / \mathrm{min}$ and rapidly open the hatch at $220^{\circ} \mathrm{C}$ and $1.96 \mathrm{MPa}$. After popping, the material was recovered in a storage tank and the wet material was cooled to ambient temperature.

\section{Chemical composition analysis}

The ethanol-benzene soluble fraction was determined gravimetrically. Klason lignin, acid-soluble lignin and the ash of raw and pretreated rice straw were analyzed in accordance with TAPPI Standard Methods [26]. Analyses of structural sugars (glucose, xylose, arabinose, mannose, galactose and rhamnose) were conducted using a gas chromatograph [14]. 


\section{Enzyme activity}

The commercial enzymes used in this study were cellulase (Celluclast 1.5 L, Novozyme) and xylanase (X2753, Sigma). Filter paper unit activity of cellulase was measured in terms of FPU/mL [27]. One filter-paper unit (FPU) was defined as the amount of enzyme required to release $1 \mu$ mole of glucose from filter paper per min. Xylanase activity was measured on the basis of xylose released from birch wood xylan as a substrate and was expressed in terms of international units (IU)/mL. One IU was defined as the amount of enzyme required to release $1 \mu$ mole of xylose from birch wood xylan per min [28]. The activities of cellulase and xylanase were $79 \mathrm{FPU} / \mathrm{mL}$ and $592 \mathrm{IU} / \mathrm{mL}$, respectively.

\section{Optimization of enzyme mixture}

Enzymatic saccharification was conducted at 1\% DM (dry matter, w/v) initial substrate loading in a conical tube $(50 \mathrm{~mL})$. A sample of pretreated rice straw was soaked in $0.1 \%(\mathrm{w} / \mathrm{v})$ yeast extract, $0.2 \%(\mathrm{w} / \mathrm{v})$ peptone and $0.05 \mathrm{M}$ citrate buffer ( $\mathrm{pH}$ 4.8). Enzymatic hydrolysis was performed at $37^{\circ} \mathrm{C}$ (the optimal temperature for xylanase) with various enzyme concentrations $(0,10,20$, 30 , and $40 \mathrm{FPU}$ cellulase $\mathrm{g}^{-1}$ biomass and $0,50,100,150$, and 200 IU xylanase $\mathrm{g}^{-1}$ biomass) for $48 \mathrm{~h}$. This hydrolytic reaction was followed by measurement of the carbohydrate levels in the hydrolyzates using a DNS assay [29]. Optimization of the cellulase to xylanase ratio was achieved using response-surface methods [30]. In this work, a central composite design was established to study the empirical relationship between the released sugar and enzyme mixtures, namely: $x_{1}$, cellulase and $x_{2}$, xylanase (Table 3). Table 3 shows the two variable replicate central composite designs used for fitting of the following quadratic model. Enzymatic conversion yield was calculated as the ratio of glucose released at $48 \mathrm{~h}$ divided by the glucose content in pretreated rice straw.

$$
y=\mathrm{a}+\mathrm{b} x_{1}+\mathrm{c} x_{2}+\mathrm{d} x_{1} x_{2}+\mathrm{ex}_{1}^{2}+\mathrm{f}_{2}{ }^{2}
$$

\section{Separate hydrolysis and fermentation}

Enzymatic saccharification was conducted in a $500 \mathrm{~mL}$ Erlenmeyer flask with a total working volume of $100 \mathrm{~mL}$ at a substrate concentration of $15 \% \mathrm{DM}(\mathrm{w} / \mathrm{v})$ with $0.1 \%(\mathrm{w} / \mathrm{v})$ yeast extract, $0.2 \%(\mathrm{w} / \mathrm{v})$ peptone, and $0.05 \mathrm{M}$ citrate buffer

Table 3 Experimental domain and level distribution used for enzyme ratio optimization

\begin{tabular}{lllllll}
\hline Variables & Coded level & \multicolumn{6}{l}{ Level } & & \\
\cline { 3 - 7 } & & $x_{1}$ & $-\mathbf{1}$ & $\mathbf{0}$ & $\mathbf{+ 1}$ & $\mathbf{+ 2}$ \\
\hline $\begin{array}{l}\text { Cellulase (FPU/g } \\
\text { biomass) }\end{array}$ & $x_{1}$ & 10 & 20 & 30 & 40 \\
Xylanase (IU/g biomass) & $x_{2}$ & 0 & 50 & 100 & 150 & 200 \\
\hline
\end{tabular}

( $\mathrm{pH}$ 4.8). Reaction flasks were run in triplicate with an enzyme loading of 23 FPU cellulase and 62 IU xylanase/g biomass at $150 \mathrm{rpm}$ for $48 \mathrm{~h}$. The flasks were then stored at $4^{\circ} \mathrm{C}$ until required fermentation.

For the fermentation with S. cerevisiae KCTC 7906, $0.5 \mathrm{~g}$ of dry yeast was added as inoculum to $100 \mathrm{~mL}$ of hydrolyzates. Fermentation was carried out at $32^{\circ} \mathrm{C}$ for $48 \mathrm{~h}$ with agitation at $150 \mathrm{rpm}$. All experiments were performed in triplicate, and ethanol yield was calculated on the basis of total glucose content in the pretreated materials by dividing the quantity of ethanol produced by the total amount of glucose.

\section{High-performance liquid chromatography (HPLC) analysis} for liquid phase

During enzymatic hydrolysis and fermentation sugars (glucose and xylose) and ethanol were monitored using HPLC equipped with a refractive index detector (YoungLin Instruments, Anyang, Korea). A Rezex ROA organic acid column (Phenomenex, Torrance, CA) was used for compound identification $(300 \times 7.8 \mathrm{~mm})$. The temperatures of the column and detector were maintained at 65 and $40^{\circ} \mathrm{C}$, respectively, and $5 \mathrm{mM}$ sulfuric acid was added to the mobile phase at a flow rate of $0.6 \mathrm{~mL}$ per min.

\section{Structural characterizations}

The surface morphologies of the samples were examined using field-emission scanning electron microscopy (FESEM) with a JSM-7500 F (Jeol, Japan) instrument operating at a beam voltage of $3 \mathrm{kV}$. Prior to observation, each sample was dehydrated with a graded ethanol series and freezedried. The external surface of the sample was then sputtercoated with osmium suing a sputter-coater.

\section{Surface area measurement using a BET}

The pore structures of rice straw and its popping pretreated materials were measured using BET nitrogen adsorptiondesorption isotherms at $-196^{\circ} \mathrm{C}$ in a surface-area analyzer (ASAP 2020, Micromeritics Co., USA). Prior to determination, the sample $(\sim 0.7 \mathrm{~g})$ was degassed for $1.5 \mathrm{~h}$ at $110^{\circ} \mathrm{C}$ under vacuum $(5 \mathrm{mmHg})$ to remove moisture and any other contaminants. The total pore volume was assessed by converting the amount of nitrogen gas adsorbed to the volume $\left(\mathrm{cm}^{3} / \mathrm{g}\right.$ at STP) of liquid adsorbate, using a single point adsorption (at a relative pressure circa 0.99 ).

\section{Additional files}

Additional file 1: Figure S1. FE-SEM photographs of rice straw powders showing the morphology of surface before (a-c) and after popping pretreatment $(\mathrm{d}-\mathrm{f})$. Note an increased in micropores (arrows) after popping pretreatment.

Additional file 2: Table S1. ANOVA of the adjusted model of the response to enzymatic hydrolysis of pretreated rice straw. 


\section{Abbreviations}

BET: Brunauer Emmett and Teller; GC: Gas chromatography; DM: Dry matter: FE-SEM: Field emission scanning electron microscopy; FPU: Filter-paper unit; HPLC: high performance liquid chromatography; IU: International unit; S. cerevisiae: Saccharomyces cerevisiae; SHF: Separate hydrolysis and fermentation.

\section{Competing interests}

The authors declare that they have no competing interests.

\section{Authors' contributions}

SGW performed the lab-scale pretreatment, enzymatic hydrolysis, chemical composition analyses including the HPLC and GC, and drafted the manuscript. ISC, KHK and HMK carried out the ethanol fermentation and the determination of ethanol content and help to draft the manuscript. HJB coordinated the study, contributed to the analysis of the results and in the improvement of the manuscript. All authors read and approved the final manuscript.

\section{Acknowledgements}

This work was supported by Priority Research Centers Program (2010-0020141) through the National Research Foundation of Korea (NRF) funded by the Ministry of Education, Science and Technology, and by a grant (S2113131L010120) from Forest Science \& Technology Projects, Forest Service, Republic of Korea.

\section{Author details}

${ }^{1}$ Bio-energy Research Center, Chonnam National University, Gwangju 500-757, Republic of Korea. ${ }^{2}$ Department of Forest Products and Technology, Chonnam National University, Gwangju 500-757, Republic of Korea. ${ }^{3}$ Department of Bioenergy Science and Technology, Chonnam National University, Gwangju 500-757, Republic of Korea.

Received: 29 May 2013 Accepted: 24 September 2013

Published: 29 November 2013

\section{References}

1. Kim S, Dale BE: Global potential bioethanol from wasted crops and crop residues. Biomass Bioenerg 2004, 26:361-375.

2. Naik SN, Goud W, Rout PK, Dalai AK: Production of first and second generation biofuels: a comprehensive review. Renew Sust Energ Rev 2010 14:578-597.

3. Sarkar N, Ghosh SK, Bannerjee S, Aikat K: Bioethanol production from agricultural wastes: an overview. Renew Energ 2012, 37:19-27.

4. McAloon A, Taylor F, Yee W, Ibsen K, Wooley R: Determining the cost of producing ethanol from corn starch and lignocellulosic feedstocks. NRELITP580-28893. Golden, CO (USA): National Renewable Energy Laboratory; 2000

5. Cherubini F, Ulgiati S: Crop residues as raw materials for biorefinery systems - A LCA case study. Appl Energy 2010, 87:47-57.

6. Galbe M, Zacchi G: A review of the production of ethanol from softwood. Appl Microbiol Biotechnol 2002, 59:618-628.

7. Wyman CE, Hinman ND: Ethanol - Fundamentals of production from renewable feedstocks and use a transportation fuel. Appl Biochem Biotechnol 1990, 24/25:735-753.

8. Balat M, Balat $\mathrm{H}, \mathrm{Öz} \mathrm{C}$ : Progress in bioethanol processing. Prog Energy Combust Sci 2008, 4:551-573.

9. Binod P, Sindhu R, Singhania RR, Vikram S, Devi L, Nagalakshmi S, Kurien N, Sukumaran RK, Pandey A: Bioethanol production from rice straw: an overview. Bioresour Technol 2010, 101:4767-4774.

10. Hu G, Heitmann JA, Rojas OJ: Feedstock pretreatment strategies. BioResources 2008, 3:270-294.

11. Mosier N, Wyman H, Dale B, Elander R, Lee YY, Holtzapple M, Ladisch M: Features of promising technologies for pretreatment of lignocellulosic biomass. Bioresour Technol 2005, 96:673-686.

12. Alvira P, Tomás-Pejó E, Ballesteros M, Negro MJ: Pretreatment technologies for an efficient bioethanol production process based on enzymatic hydrolysis: A review. Bioresour Technol 2010, 101:4851-4861.

13. Li Q, He YC, Xian M, Jun G, Xu X, Yang JM, Li LZ: Improving enzymatic hydrolysis of wheat straw using ionic liquid 1-ethyl-3-methyl imidazolium diethyl phosphate pretreatment. Bioresour Technol 2009, 100:3570-3575.
14. Wi SG, Chung BY, Lee YG, Yang DJ, Bae H-J: Enhanced enzymatic hydrolysis of rapeseed straw by popping pretreatment for bioethanol production. Bioresour Technol 2011, 102:5788-5793.

15. Choi IS, Kim J-H, Wi SG, Kim KH, Bae H-J: Bioethanol production from mandarin (Citrus unshiu) peel waste using popping pretreatment. Appl Energy 2012, 102:204-210.

16. Choi IS, Wi SG, Kim S-B, Bae H-J: Conversion of coffee residue waste into bioethanol with using popping pretreatment. Bioresour Technol 2012, 125:132-137.

17. Lv S, Yu Q, Zhuang X, Yuan Z, Wang W, Wang Q, Qi W, Tan X: The Influence of hemicellulose and lignin removal on the enzymatic digestibility from sugarcane bagasse. Bioenerg Res 2013. DOI 10.1007/ s12155-013-9297-4

18. Zhao X, Cheng K, Liu D: Organosolv pretreatment of lignocellosic biomass for enzymatic hydrolysis. Appl Microbial Biotechnol 2009, 82:815-827.

19. Tabka MG, Herpoel-Gimbert I, Monod F, Asther M, Sigoillot JC: Enzymatic saccharification of wheat straw for bioethanol production by a combined cellulase xylanase and feruloyl esterase treatment. Enzyme Microb Tech 2006, 39:897-902.

20. Romaní A, Garrote G, Parajó JC: Bioethanol production from autohydrolyzed Eucalyptus globulus by Simultaneous Saccharification and Fermentation operating at high solids loading. Fuel 2012, 94:305-312.

21. Palmqvist E, Hahn-Hägerdal B: Fermentation of lignocellulosic hydrolysates. I: inhibition and detoxification. Bioresour Technol 2000, 74:17-24.

22. Abedinifar S, Karimi K, Khanahmadi M, Taherzadeh MJ: Ethanol production by Mucor indicus and Rhizopus oryzae from rice straw by separate hydrolysis and fermentation. Bioresour Technol 2009, 33:828-833.

23. Chen W-H, Lin T-S, Guo G-L, Huang W-S: Ethanol production form rice straw hydrolysates by Pichia stipitis. Energy Procedia 2012, 14:1261-1266.

24. Karimi K, Emtiazi G, Taherzadeh MJ: Ethanol production from dilute-acid pretreated rice straw by simultaneous saccharification and fermentation with Mucor indicus, Rhizopus oryzae, and Saccharomyces cerevisiae. Enzyme Microbial Technol 2006, 40:138-144.

25. Ko JK, Bak JS, Jung MW, Lee HJ, Choi IG, Kim TH, et al: Ethanol production from rice straw using optimized aqueous-ammonia soaking pretreatment and simultaneous saccharification and fermentation processes. Bioresour Technol 2009, 100:4374-4380.

26. TAPPI Committee: TAPPI test methods. Atlanta, GA (USA): TAPPI Press; 1992.

27. Adney B, Baker J: Measurement of cellulase activities. NREL/TP-510-42628. Golden, CO (USA): National Renewable Energy Laboratory; 2008.

28. Teixeira RSS, Siqueira FG, Souza MVD, Filho EXF, Bon EPDS: Purification and characterization studies of a thermostable $\beta$-xylanase from Aspergillus awamori. J Ind Microbiol Biotechnol 2010, 37:1041-1051.

29. Miller $\mathrm{GL}$ : Use of dinitrosalicylic acid reagent for determination of reducing sugar. Anal Chem 1959, 13:426-428.

30. Box GEP, Wilson KG: On the experimental attainment of optimum conditions. J R Stat Soc Ser B-Stat Methodol 1951, 13:1-45.

\section{doi:10.1186/1754-6834-6-166}

Cite this article as: Wi et al:: Bioethanol production from rice straw by popping pretreatment. Biotechnology for Biofuels 2013 6:166.

\section{Submit your next manuscript to BioMed Central and take full advantage of:}

- Convenient online submission

- Thorough peer review

- No space constraints or color figure charges

- Immediate publication on acceptance

- Inclusion in PubMed, CAS, Scopus and Google Scholar

- Research which is freely available for redistribution 